admitted practical difficulties of such work". At Dale Fort, 917 spent a week at the ceritre during the year, this being 228 more than in the previous year. Of these, 621 were biologists, 137 geographers, while the remainder pursued other studies. The proportion of amateur naturalists rose steeply; but sixth-form school students were still the largest category. Despite excellent facilities for botanical studies, in 1953 only one party of botanists made use of the centre. Flatford Mill also reported an increase in numbers attending, and this despite the effects of the east coast floods in January 1953. At Juniper Hall there was an increase of a hundred students over the previous year, 10 per cent of the total attendance being made up of students from Germany, and various individual students and workers attending the centre independently of educational institutions. The largest number of students at any centre was at Malham Tarn, which had a total of 1,132; one of the main events during the year at this centre was the annual field meeting of the British Ecological Society in July 1953.

In spite of the Council's fine record, however, the financial situation is causing the executive committee continuing concern, and its chairman, Prof. S. W. Wooldridge, appeals for financial support from those who believe in its aims and approve its methods. Without increased financial support the Council can neither contemplate any improvement of its work, however modest, nor, what is perhaps even more important, get such relief from unremitting financial pressure as might enable officers to plan a little way ahead.

\section{Higher Education in China}

THE visit of a party to China in 1952, made up of members of Parliament, university professors, men of science, doctors, journalists, lawyers, actors, trade union officials and an architect and a musician, is described by Dr. D. M. Ross, a member of the party, in a recent issue of the Universities' Review (26, No. 2; February 1954). The party went, as guests of the Chinese People's Institute of Foreign Affairs, and those interested were able to visit a number of universities and talk to many university teachers during the month they spent in China. Dr. Ross reports that "the stage is set for advances in higher education in that country of staggering dimensions". Within twenty years university students in China should be counted in millions, and university teachers in tens, or hundreds, of thousands. In another article, Dr. F. C. Jones discusses the way in which Chinese university teachers have fared under sovietization. Some, perhaps the wisest, have fled to the United States. Others have resisted and have been dismissed, imprisoned or driven to suicide. Most have submitted, some through successful indoctrination, others because they have to live. Dr. Jones believes that the Chinese university teacher "will continue to be deprived of all real freedom of thought or expression; he will be compelled to teach what he at heart knows to be false and he will not be permitted even silent disapproval". He will also have a minimum of contact with the outside world, save only the Soviet Union.

\section{Bibliography of Seismology}

THe very valuable "Bibliography of Seismology", comprising both pure and applied branches of the subject, and compiled by W. G. Milne, continues to be issued by the Dominion Observatory, Ottawa
(Vol. 14, Nos. 9-12; 1952-53. Ottawa: Queen's Printer; 25 cents each number). The bibliography is as complete as the author can make it, and co-operation is invited. Items in recently published numbers include some from the U.S.S.R. and an increasing number from Turkey. During 1951 most entries in the bibliography were concerned with, in order, seismic prospecting, wave studies from observations, and general description of earthquakes; whereas during 1952 they were about wave studies from observations, mathematical physics applied to seismology, surface waves, seismic prospecting and studies of the earth's crustal structure. Considerable interest is at present evident among seismologists concerning the possibility of lowvelocity layers in the upper part of the earth. Earthquakes giving good instrumental records at epicentral distances up to $30^{\circ}$ are being studied for evidence of these layers, and the theoretical aspects and consequences of such possible layers are being considered. Notes and papers on this topic are listed in the bibliography, including work by Gutenberg, Jeffreys, Stoneley and others. A paper listed as item 7985 by Jean De Bremaecker, "Amplitudes of $P_{n}$ waves from $3^{\circ}$ to $23^{\circ}$ (abstract) (Bull. Geol. Soc. America, 63, No. 12, Part 2, 1350 ; December 1952), also calls to mind the very valuable new seismograph station at Lwiro in the Belgian Congo. There is room for many more seismograph stations in Africa.

\section{New Spitsbergen Ostracoderms}

A RFCENT publication, "Morphologic and Systematic Studies of Spitsbergen Cephalaspids", by Gustav Wängsjö (The Downtonian and Devonian Vertebrata of Spitsbergen; IX. Part A, pp. 615. Part B, pp. 42 and 118 half-tone plates. Norsk Polarinstitutt, 1952), brings to mind E. A. Stensiö's remarkable work on the same group in 1927 which marked the beginning of a new era in our knowledge of the Ostracoderms. A great deal of investigation has been done since then, much of it by Stensiö's school or under his inspiration. Two expeditions. have brought back considerable collections from Spitsbergen, that of Th. Vogt in 1928 and the English-Norwegian-Swedish expedition under the leadership of Stensiö in 1939. A thorough examination of this, together with a reinvestigation of Stensiö's material where desirable, has enabled G. Wängsjö to record sixty-three new species of cephalaspids and to provide further information concerning a number of others. The use of new techniques, including staining with alizarin, revealed many details of the anatomy, internal and external, and the author devotes 205 pages to this aspect and makes valuable additions to our knowledge. When discussing the phylogenetic relationships of the group, Stensiö divided the Ostracodermi (primitive cyclostomes) into two groups, the first containing the Petromyzontes, Anaspida and Osteostraci, and the second containing the Myxinoidea, Palaeospondylus and the Heterostraci. This, as will be seen, divides the living cyclostomes between two widely separated groups. Subsequent work has modified this suggestion. First, Palreospondylus has been removed from the Agnatha and placed with the Gnathostomata; secondly, the myxinoids are considered so closely related to the petromyzonts that they must be included in the same order ; and lastly, the Heterostraci are now regarded as well removed from the others with which they have only a remote connexion. With these views the author is in agree- 